\title{
Kolonizowanie historii. Postkolonializm i postsocjalizm jako komunały ${ }^{1}$
}

\section{Abstract \\ Colonising of History. Postcolonialism and Postsocialism as Commonplaces}

Drawing on Eric R. Wolf famous appeal that anthropology bears a special responsibility to examine the commonplaces of human thought and the fighting words of human speech (Wolf 1994), in this essay I consider some aspects of postcolonialism and postsocialism specific understanding in a public culture - especially in Poland and, to lesser extent, other formerly dependent nationstates: Fiji and Jamaica. Public culture itself is, in a sense, a common place where numerous terms and arguments of academic origins are losing their previous meaning and acquire new senses. They are often objects of abuse and semantic manipulations in order to impose a specific interpretations of the past - which is the colonizing of the history - that are instrumental to justify domination of the particular socio-political policies.

Keywords: anthropology of history, political anthropology, postsocialism, postcolonialism, Poland

1 Pisząc o „komunałach”, mam na myśli znaczenie tego terminu właściwe dla greckiego koinos topos czy łacińskiego locus commūnis, oznaczających powszechnie dostępne miejsce, które może dać okazję do spotkań, ale może też zostać użyte do własnych celów przez każdego użytkownika, a przez niektórych zawłaszczone lub zbezczeszczone. Zdaję sobie sprawę, że słowo to w polszczyźnie wywołuje raczej negatywne konotacje, jednak jego wydźwięk to kwestia interpretacji. 
Relacja między profesjonalnym dialektem i bardziej ogólnym dyskursem powinna być rozumiana jako część szerszej interakcji między antropologia a innymi rodzajami publicznej wiedzy (public understanding). Ta dyscyplina nie wyskoczyła jak Atena z głowy Zeusa; ona się wyłoniła $z$ kotłów konfliktów, $w$ których upichcono wiele $z$ mordeg i trosk minionych stuleci, i odpowiada - musi odpowiadać - na działania tych sił, nawet gdy dąży do profesjonalnego dystansu i beznamiętnej neutralności. Dokładnie dlatego, że jest zarówno potomstwem i krytyczka naszej kondycji, to ponosi specjalna odpowiedzialność za sprawdzanie komunałów naszej myśli i walczących słów naszej mowy oraz poddawanie ich rozsądnej analizie.

Eric R. Wolf 1994: 1-2

Esej ten wziął się z mojej potrzeby przemyślenia sposobu, w jaki dyskursy intelektualne przenikają kulturę publiczną, a raczej jak rozmywają się w niej. $\mathrm{Mu}-$ szę zaznaczyć już na wstępie, że ma on charakter bardziej przyczynku niż wyjaśnienia. Mam w wyniku pracy nad nim więcej pytań niż odpowiedzi, poruszam się bowiem w materii żywej, której kształt się dynamicznie zmienia. Jesteśmy na przykład świadkami wojny w Syrii, która jest skutkiem zarówno postsocjalizmu, jak i postkolonializmu - w teorii oraz w praktyce - a jej przerażające konsekwencje docierają do nas wraz z falami uchodźców i kompromitacją naszego państwa na polu solidarności z ludźmi w potrzebie oraz współpracy europejskiej. Rodzi to wiele kwestii, których nie byłem w stanie w tym opracowaniu uwzględnić, również dlatego, że nie prowadziłem na ten temat odpowiednich badań. Mam nadzieję, że choć daleki od doskonałości, ten pełen niedopowiedzeń artykuł zostanie potraktowany jako pożyteczna próba włączenia się w dyskusję, która ma ogromne znaczenie dla naszej przyszłości.

Określenia „postkolonializm” czy „postsocjalizm” często znamionują nadmierną koncentrację używających ich uczestników kultury publicznej na pewnych fazach procesów i zjawisk historycznych, odwracając uwagę od tego, co poprzedzało i otaczało opisywane w nich zjawiska, oraz determinują sposoby ich odczytywania i wyjaśniania. Mam tu na myśli zwłaszcza systemy wartości leżące u ich praźródeł, a także te zjawiska i procesy, które należy i można ujmować również w innych ramach analitycznych. W tym sensie określenia te wyznaczają domyślną cezurę - w kontekście postkolonializmu - do czasu kolonizacji, a w przypadku postsocjalizmu - do okresu funkcjonowania specyficznego ustroju. Dotyczy ona przede wszystkim rodzaju odcięcia się od stanu przed pojawieniem się odpowiednich relacji zależności na danym obszarze. Jest oczywiste, iż kolonializm i socjalizm prowadziły do wytworzenia nowych zjawisk i procesów, których konsekwencje można i należy śledzić po formalnym zakończeniu tych form podległości. Nie 
ulega wątpliwości, iż formalna czy też odczuwana podległość wytwarza nowe jakości w interakcji z zastanymi zjawiskami społecznokulturowymi, które ulegają pod jej wpływem modyfikacjom i reinterpretacjom² ${ }^{2}$. Jednak, jako Wolfowskie komunały i słowa wykorzystywane do bieżącej walki o dyskursywną władzę, są wykorzystywane w celu kolonizacji historii. Ma ona dwojaki zasięg. Po pierwsze służy do przekonania odbiorców kultury publicznej do uznania uprzywilejowanego statusu grup aktualnie dominujących kulturowo i/lub politycznie (np. na podstawie uznania ich historycznych zasług lub ofiar). Po drugie, w ramach kolonizacji wiedzy o przeszłości, często przy użyciu przemocy symbolicznej lub fizycznej, narzuca się zmianę odczytywania historii, a czasem wręcz modyfikuje przebieg dawnych wydarzeń w sposób niewynikający z nowych ustaleń historyków, lecz z prowadzonej w mniej lub bardziej przemyślany sposób realizacji celów, jakie stawiają przed sobą podejmujący się kolonizacji aktorzy kultury publicznej.

Jako rozległe obszary problemowe, zarówno postkolonializm, jak i postsocjalizm (nawet jeśli są nazywane inaczej - patrz np. Kołodziejczyk 2010; zob. też Buruma, Margalit 2005), inspirują kolejne pokolenia badaczy do studiów nad poszczególnymi tematami. Jednak w kulturze publicznej często kładzie się na tej tematyce cień nacjonalizmu metodologicznego, etnocentryzmu lub fakt nadmiernego, „sedentarystycznego" skupiania się przez jej aktorów na wyselekcjonowanych aspektach - i w tym sensie pomijania kwestii zróżnicowania i mobilności ludzi i grup, które są przedmiotem opisu. Dotyczy to zwłaszcza statycznych i prezentystycznych podejść do etniczności, narodowości i terytoriów geopolitycznych, abstrahujących od złożonych i zróżnicowanych procesów historycznych, które doprowadziły do wytworzenia współczesnych reprezentacji siebie, Innego, tożsamości, tradycji, kultur i społeczeństw.

W wielu przypadkach jego zastosowań w kulturze publicznej „postkolonializm" nie stanowi krytycznego nurtu refleksji, ale ulega redukcji do roli oręża, wskutek zawłaszczenia przez ideologów, którzy nie wahają się nadużywać osiągnięć krytyków postkolonialnych w celu manipulacji (w przypadku polskich dyskursów publicznych świetnie wykazał to Stanley Bill; zob. Bill 2014 a i b). „Postkolonializm”, a także "postsocjalizm” bywają celowo lub bezrefleksyjnie stosowane jako określenia esencjalizujące i reifikujące, stanowiąc historycystyczny (Popper 1957) element identyfikacji i wyjaśniania wobec całych społeczeństw i regionów ${ }^{3}$.

2 Pragnę się odnieść do tych kwestii, opierając się na doświadczeniach z badań terenowych prowadzonych w dawnych koloniach brytyjskich (Fidżi 2000-2007, Jamajka 2009-2012) oraz na „postsocjalistycznym” pograniczu polsko-niemieckim (z Pawłem Ładykowskim 2009-2012). Badania dotyczyły konstruowania tożsamości na obszarach „postpodległościowych”, to znaczy takich, gdzie problematyka historycznych zależności od władzy i wpływów kulturowych „sił zewnętrznych" stanowi ważny aspekt repertuaru autoidentyfikacji i auto- oraz egzoreprezentacji zamieszkujących je zbiorowości.

3 Odnoszę wrażenie, że określenia takie jak „obszary postsocjalistyczne” i „postkolonialne” stanowią dziś coraz częściej ekwiwalent wycofywanych z użycia terminów „Drugi” i „Trzeci Świat”, które zawierały ładunek deprecjonujący całe geohistoryczne czy geopolityczne regiony wobec „Pierw- 
Świeżej inspiracji do tego eseju dostarczyła mi aktualnie odbywająca się w kulturze publicznej debata nad odpowiedzialnością Polski za historyczne zbrodnie i niegodziwości dokonywane przez ludzi utożsamianych z polskością przeciwko sąsiadom oraz na Polakach przez sąsiadów ${ }^{4}$. Wielu jej uczestników stosuje interesujące zabiegi retoryczne w kontekście ustalania, czy winne są jednostki, czy całe narody, a zatem w jakich okolicznościach państwa narodowe powinny się przyznawać do odpowiedzialności za czyny popełnione przez przedstawicieli narodu. Problem ten ma aspekt zarówno postkolonialny, jak i postsocjalistyczny, i to już na bardzo powierzchownym poziomie analizy, gdyż wskazuje się, że nie może być mowy o odpowiedzialności państwa narodowego za czyny popełnione przez jego obywateli i instytucje wówczas, gdy nie było niepodległe (nawet w sytuacji formalnej suwerenności PRL) lub znajdowało się pod okupacją. Premier Mateusz Morawiecki zapewnia, iż „[p]o przyjęciu Żydów przez Władysława Hermana suwerenna polska władza nigdy nie wypędzała Żydów, czyli nie robiła tego, co właściwie zrobiły suwerenne władze we wszystkich innych państwach europejskich. Wręcz przeciwnie - poprzez przywileje tworzyła dobrą przestrzeń do życia, której Żydzi nie mieli w żadnym innym kraju ówczesnej Europy" (Morawiecki 2018a). W swym kolejnym wystąpieniu, w Monachium, twierdził on wręcz, iż w 1968 roku „Polska nie istniała” (Wirtualna Polska 2018; Wieliński 2018). Następnie złożył kwiaty na grobach żołnierzy Brygady Świętokrzyskiej, najbardziej znanej polskiej organizacji zbrojnej, która w sposób jawny współpracowała $\mathrm{z}$ hitlerowcami i wraz z nimi wycofała się z terenu okupowanej Polski.

Premier daje tą wypowiedzią do zrozumienia, iż uważa okres od II wojny światowej do co najmniej 1989 roku za czas, gdy Polska nie była państwem suwerennym, przez co nie powinna ponosić dziś odpowiedzialności za czyny swych władz i polskich organizacji (w tym np. PZPR), co jest dość często artykułowanym przekonaniem części aktorów kultury publicznej w Polsce. Stoi to w dość ciekawym kontraście z faktem, iż dyskusja ta jest prowadzona w związku z nowelizacją ustawy o Instytucie Pamięci Narodowej (IPN), której twórcy uzupełnili zakres działań IPN o badanie „zbrodni ukraińskich nacjonalistów i członków ukraińskich formacji kolaborujących z Trzecią Rzeszą Niemiecką", przez co poszerzyli katalog czynów podlegających karze grzywny lub więzienia do lat $3 \mathrm{w}$ obowiązującej ustawie (rozdz. 7, art. 55) o „publiczne i wbrew faktom” zaprzeczanie tego rodzaju zbrodniom (Dz.U. 2018 poz. 369; Dz.U. 1998 nr 155 poz. 1016). Kontrast

szego Świata”, czyli tzw. Zachodu. Zaznaczyć należy, że Alfred Sauvy, który ukuł terminologię trzech światów, parafrazując system trzech stanów przedrewolucyjnej Francji, miał na celu uzmysłowienie czytelnikom, iż Trzeciego Świata nie wolno ignorować, eksploatować i poniżać (Sauvy 1952). Ciekawa jest także kariera pojęcia homo sovieticus, którego manipulacyjne wykorzystanie skrytykował Michał Buchowski (Buchowski 2013: 32-41).

4 Termin „sąsiedzi” (za: Gross 2000) rozciągam tutaj na wszystkie sytuacje tego rodzaju, do których dochodziło także w relacjach z przedstawicielami innych niż Żydzi grup zamieszkujących obszar przedwojennej Polski. 
ten polega na tym, iż Rzeczpospolita Polska jest prawnym kontynuatorem PRL, która była formalnie niepodległym państwem, na Ukrainie zaś nie udało się utworzyć niepodległego państwa aż do rozpadu ZSRR. W okresie objętym działaniem znowelizowanej ustawy o IPN w zakresie zbrodni ukraińskich nacjonalistów i członków formacji kolaborujących z III Rzeszą ustawodawca precyzuje w art. 2a:

Zbrodniami ukraińskich nacjonalistów i członków ukraińskich formacji kolaborujących z Trzecią Rzeszą Niemiecką, w rozumieniu ustawy, są czyny popełnione przez ukraińskich nacjonalistów w latach 1925-1950, polegające na stosowaniu przemocy, terroru lub innych form naruszania praw człowieka wobec jednostek lub grup ludności. Zbrodnią ukraińskich nacjonalistów i członków ukraińskich formacji kolaborujących z Trzecią Rzeszą Niemiecką jest również udział w eksterminacji ludności żydowskiej oraz ludobójstwie na obywatelach II Rzeczypospolitej na terenach Wołynia i Małopolski Wschodniej.

Innymi słowy, premier Morawiecki, twierdząc, iż naród i państwo polskie nie ponoszą odpowiedzialności za czyny popełniane w okresie podległości, w tym także w okresie PRL, per analogiam dostarcza argumentów dla tezy, że państwo ukraińskie nie ponosi odpowiedzialności za czyny popełnione przed 1991 rokiem, w tym te wskazane w ustawie. Dodatkowo, składając kwiaty na grobach żołnierzy Brygady Świętokrzyskiej, daje do zrozumienia, że - odpowiednio - rząd polski zamierza zrezygnować z tytułu do potępiania upamiętniania „wyzwoleńczych” organizacji kolaborujących $\mathrm{z}$ hitlerowcami na przykład na Ukrainie.

A jednak tak nie jest. Deklarowaną intencją działań Morawieckiego i jego zaplecza politycznego oraz współpracującej przy nowelizacji partii Kukiz 15' była chęć „walki o dobre imię Polski”. Ustawa zawiera bowiem artykuł 55a i b w brzmieniu:

Art. 55a. 1. Kto publicznie i wbrew faktom przypisuje Narodowi Polskiemu lub Państwu Polskiemu odpowiedzialność lub współodpowiedzialność za popełnione przez III Rzeszę Niemiecką zbrodnie nazistowskie określone w art. 6 Karty Międzynarodowego Trybunału Wojskowego załączonej do Porozumienia międzynarodowego w przedmiocie ścigania i karania głównych przestępców wojennych Osi Europejskiej, podpisanego w Londynie dnia 8 sierpnia $1945 \mathrm{r}$. (Dz. U. z 1947 r. poz. 367), lub za inne przestępstwa stanowiące zbrodnie przeciwko pokojowi, ludzkości lub zbrodnie wojenne lub w inny sposób rażąco pomniejsza odpowiedzialność rzeczywistych sprawców tych zbrodni, podlega grzywnie lub karze pozbawienia wolności do lat 3. Wyrok jest podawany do publicznej wiadomości.

2. Jeżeli sprawca czynu określonego w ust. 1 działa nieumyślnie, podlega grzywnie lub karze ograniczenia wolności.

3. Nie popełnia przestępstwa sprawca czynu zabronionego określonego w ust. 1 i 2, jeżeli dopuścił się tego czynu w ramach działalności artystycznej lub naukowej.

Art. 55b. Niezależnie od przepisów obowiązujących w miejscu popełnienia czynu zabronionego niniejszą ustawę stosuje się do obywatela polskiego oraz cudzoziemca w razie popełnienia przestępstw, o których mowa w art. 55 i art. 55a.

Lider Zjednoczonej Prawicy i prezes PiS Jarosław Kaczyński, który wzywa do zerwania z „pedagogiką wstydu” („Odrzucamy politykę pedagogiki wstydu. Idziemy w kierunku Polski, która będzie mogła powiedzieć, że jest krajem niepodleg- 
łym i dumnym” - Kaczyński 11.11.2017 [pis.org.pl]), uzasadnia, dlaczego nowelizacja została przegłosowana w przeddzień Międzynarodowego Dnia Pamięci o Ofiarach Holocaustu:

Zdecydowaliśmy się na to, uznając, że w końcu trzeba sprawę zamknąć. Przy czym podkreślam, że przez cały czas chodziło o Ukrainę, bo to była jedyna sporna kwestia. Uznaliśmy, że nie da się zaprzeczyć, że zbrodnicze organizacje odpowiedzialne za mordy na Polakach były ukraińskie, i trzeba być tu po prostu w zgodzie z prawdą. Zatem był spór o Ukrainę, a tu nagle jak grom z jasnego nieba spadła na nas reakcja ze strony Izraela („Do Rzeczy” 2018: 19).

Chwilę później dodaje, że:

Przez lata nie mieliśmy żadnej polityki historycznej, nie robiliśmy tego, co należało, czyli nie odwoływaliśmy się do złego sumienia zachodnich sojuszników. Pamiętam, jak w 1991 r. wicekanclerz i minister spraw zagranicznych Austrii (...) radził mi, byśmy wykorzystywali to, że zachodnie kraje mają wobec nas nieczyste sumienie. Mówił, że to potężna broń w polityce. Tymczasem u nas zaczęto wzbudzać wyrzuty sumienia, ale u Polaków. To było coś fatalnego. Teraz jesteśmy na początku kontrofensywy („Do Rzeczy” 2018: 19).

Opisywana sytuacja jest symptomatyczna dla polityki historycznej uprawianej w wielu krajach, w których politycy diagnozują deficyt godności narodowej lub wskazują na próby jej naruszenia przez wewnętrznych i zewnętrznych „nieprzyjaciół” rzekomo lub faktycznie niewykazujących oczekiwanego zrozumienia dla skomplikowanej historii państwa i społeczeństwa. Opiera się ona na założeniu, że mają rację bytu „historie narodowe”, które muszą zostać odpowiednio opowiedziane, tak by naród mógł z nich czerpać dumę i legitymizację dla swych działań historycznych, jak również tych podejmowanych dla realizacji bieżących interesów. Taka „polityka historyczna”, która zakłada jednoznaczną afirmację elementów dziejów interpretowanych jako chwalebne, przy jednoczesnym bagatelizowaniu, usprawiedliwianiu i relatywizowaniu niegodziwości, praktycznie zawsze, wbrew intencjom promotorów, prowadzi jednak do dyskusji, które umniejszają rangę afirmowanych „sukcesów”, a zwiększają świadomość na temat wstydliwych spraw, które próbowano przemilczeć ${ }^{5}$. To, z kolei prowadzi do prób sterowania kulturą publiczną, tak aby niepożądane argumenty nie trafiały do ogółu społeczeństwa, a zwłaszcza do systemów szkolnictwa. Cenzuruje się także twórczość artystyczną oraz działalność organizacji pozarządowych. W pewnym sensie, jak uważam, omawiana ustawa jest formą oficjalnego przyznania się do porażki części aktorów kultury publicznej, którzy w obliczu merytorycznej nieskuteczności

5 Tak stało się z „polityką historyczną” PRL, w ramach której próbowano przemilczeć np. historię 20-lecia międzywojennego, zbrodni katyńskiej czy represji tzw. okresu stalinowskiego. Jednak dodać należy, iż ta świadoma i złożona polityka, która w wielu wątkach stanowiła kontynuację etnocentrycznej historiografii polskiej okresu rozbiorów i 20-lecia międzywojennego, wywarła wpływ na świadomość historyczną dużej liczby Polaków, którzy nie dowiedzieli się także o wielu wydarzeniach dziejowych, mogących dodatkowo osłabiać skuteczność współczesnej „polityki historycznej". 
promowanej „polityki historycznej” sięgają po argument siły, by przy użyciu aparatu przemocy móc kontynuować kolonizację historii.

W każdej z badanych przeze mnie społeczności interpretacja różnie definiowanej i praktycznie zorganizowanej podległości - historycznej lub wskazywanej współcześnie - nakładała się na proces kształtowania „nowożytnych” tożsamości narodowych (Anderson 1997) oraz „wynajdywania tradycji” (Hobsbawm, Ranger 2008), do którego walnie przyczynili się - i w dalszym ciągu się przyczyniają naukowcy. Na dyskursy tożsamościowe badanych społeczności w dalszym ciągu silnie oddziałują wyobrażenia, które ukształtowały się na Fidżi - w okresie rządów pośrednich, które doprowadziły do wytworzenia społeczeństwa mnogiego, na Jamajce - niewolnictwa i późniejszych rządów opartych na stratyfikacji rasowej na Jamajce, a w Polsce - zaborów, wojen światowych, socjalistycznej satelitarności wobec ZSRR oraz tworzenia "homogenicznego" społeczeństwa. Jest to wyraźnie widoczne w sferze kultury publicznej (rozumianej za: Ortner 2004) i stanowi częsty punkt odniesienia dla analiz naukowych, dziennikarskich i politycznych, a także istotny motyw w sztuce.

W kontekście Fidżi i Jamajki, dawnych kolonii brytyjskich, w których angielski stanowi główny język kultury publicznej, istnieje długa tradycja perspektywy antykolonialnej i postkolonialnej, a co najmniej od przełomu lat siedemdziesiątych i osiemdziesiątych, w związku $\mathrm{z}$ formalną dekolonizacją tych państw, można mówić o dużym znaczeniu, jeśli nie o dominacji, „myśli postkolonialnej” (postcolonialism) w krajowych i międzynarodowych analizach społeczno-kulturowych dotyczących tych krajów ${ }^{6}$. Jamajka uzyskała autonomię w 1958 roku, a niepodległość w 1962, Fidżi zaś w 1970. W kulturze publicznej obu krajów dużą rolę odgrywał dyskurs antykolonialny, choć przyznać trzeba, że w przypadku Fidżi był on mniej żywotny. Mocniejsze piętno na najnowszych dziejach tego państwa wywarł natomiast „godnościowy nacjonalizm” nacechowany ksenofobią skierowaną przeciwko licznej mniejszości indyjskiej. Władzę w tym państwie przejęły te elity rdzennie fidżyjskie, które wcześniej aktywnie uczestniczyły w systemie rządów pośrednich, podczas gdy najaktywniejszy udział w walce o prawa podporządkowanych brali Indusi. Od początku swej spowodowanej brytyjskim kolonializmem bytności na Fidżi byli oni jako grupa pozbawieni większości praw obywatelskich i pracowniczych. Ich aktywni przedstawiciele pozostawali jednak w żywym kon-

${ }^{6}$ Jeśli przyjmiemy definicję, że postkolonializm to krytyczna, interdyscyplinarna tradycja eksplorująca wpływ kolonialnej władzy na kultury kolonizujących i kolonizowanych ludów w przeszłości oraz reprodukowanie kolonialnych relacji, reprezentacji i praktyk w teraźniejszości (Gregory 1997: 369). Co prawda niekiedy za początek „teorii postkolonialnej” uznaje się publikację Orientalizmu Edwarda Saida z 1978 r., trzeba jednak zwrócić uwagę na to, że Said nie działał w próżni, a jego prace były poprzedzone innymi dociekaniami twórców, takich chociażby jak Frantz Fanon, który zwracał uwagę na wchodzenie kolonizowanych w role kolonizatorów, czy przedstawicieli Brytyjskich Studiów Kulturowych, a także badaczy kształtowania się brytyjskiej myśli imperialnej i jej wpływu na politykę i kulturę, takich jak Bernard Semmel (1960), Bernard Cohn (1996) czy Hugh Tinker (1974). 
takcie z wydarzeniami, ideami i praktykami oporu mającymi miejsce w Indiach końca XIX i pierwszej połowy XX wieku (Kaczmarek 2008).

Populacja Jamajki była natomiast w całości napływowa - rdzenni mieszkańcy zaniknęli na skutek etnocydu i fizycznej eksterminacji. Nowa ludność stanowiła w rozumieniu Stuarta Halla (2008) metaforyczną diasporę i była zdominowana przez ludzi, których identyfikowano przez pryzmat ich pochodzenia, czy wręcz wymiejscowienia, z innych obszarów świata: Afryki, Europy, Azji (np. z Indii, Chin, Lewantu). W okresie kolonialnym ta różnorodność była poddana systemowi stratyfikacji etnorasowej, w której na szczycie hierarchii stali najmniej liczni Europejczycy, a na dole - ci najliczniejsi o afrykańskich korzeniach. Dość wspomnieć, że ci ostatni otrzymali pełne prawa wyborcze dopiero w 1945 roku (Sherlock, Bennett 1998: 251). Stąd zagadnienia nierówności opartej na rasie i klasie zasilały na Jamajce dyskurs antykolonialny, którego ważnymi elementami były opór i dążenie do emancypacji ludności poddanej pigmentokracji (Garvey 1923; Nettleford 1972; zob. też Kaczmarek 2014).

W polskiej kulturze publicznej od przełomu XVIII i XIX wieku rozwinęły się silne nurty oporu intelektualnego przeciw zaborom opierające się na historyzmie (rozumianym za: Chakrabarty 2011: 7) ukazującym należne Polsce, poczesne miejsce wśród narodów „Zachodu”. Historyzm ten redefiniował naród polski i legitymizował jego prawo do suwerenności. Wprowadzał też w sferę polityczną grupy, „które według standardów dziewiętnastowiecznego liberalizmu europejskiego wydawały się zupełnie nieprzygotowane do wzięcia na siebie odpowiedzialności za samostanowienie" (Chakrabarty 2011: 10)7. Narracje te znacząco wpłynęły na dyskursy niepodległościowe i reżim nacjonalistycznej tożsamości kultywowany zarówno po 1918 roku w warunkach społeczeństwa heterogenicznego, jak i, z pewnymi modyfikacjami, w okresie zależności od ZSRR, w czasie której doprowadzono metodami politycznymi do formalnej homogenizacji etniczno-kulturowej, a także po 1989 roku.

W odniesieniu do tak zwanych Ziem Odzyskanych, do których należą okolice Szczecina, gdzie prowadziliśmy badania z Pawłem Ładykowskim, ten gotowy reżim tożsamości posłużył ich polonizacji, polegającej na rozwijaniu narracji legitymizującej „historyczną polskość” tych obszarów, na których ludność polska pojawiła się głównie w wyniku akcji osiedleńczej (kolonizacyjnej) prowadzonej po zakończeniu II wojny światowej. Stanowiąca tam wcześniej dominującą politycznie i kulturowo większość ludność niemiecka, na skutek porozumienia mo-

Na gruncie polskim chodzi tu przede wszystkim o wielojęzyczny i wieloreligijny „lud” w kontekście odwlekania uznania jego podmiotowości (np. walka i dyskusje dotyczące zniesienia pańszczyzny, który to proces przebiegał różnie w zależności od bieżącej sytuacji politycznej w poszczególnych zaborach) oraz działań mających na celu określenie narodowości poszczególnych grup etnograficznych i etnicznych, nabierających rozmachu wraz z rozwojem „etnograficznego archiwum”, którego twórcy często podejmowali decyzje na temat przynależności narodowej „przedmiotów opisu" ponad głowami tworzących je ludzi (przeciwko czemu protestował np. Józef Obrębski w 1936 r.). 
carstw i późniejszych umów polsko-niemieckich, prawie w całości została zmuszona do wyjazdu w głąb Niemiec. Tylko nieznaczna część Niemców dobrowolnie opuściła te tereny.

Zdawałoby się, że w odniesieniu do okolic Szczecina implikowane przez dyskurs „Ziem Odzyskanych” stosowanie de facto retoryki postkolonialnej, a zwłaszcza perspektywy dekolonizacyjnej w polskiej kulturze publicznej po II wojnie światowej, powinno napotkać znaczne przeszkody (zob. Strauchold 2012). Tereny te tylko epizodycznie zależały od Polski w sensie prawnym (po podboju Bolesława Krzywoustego, którego namiestnik Racibor stał się protoplastą dynastii panującej Księstwa Pomorskiego - Gryfitów; istnieje też hipoteza, że już Mieszko I podporządkował te ziemie, jednak wiele wskazuje na to, że do 1945 roku nigdy faktycznie do Polski nie należały). Przez większość swej historii stanowiły autonomiczne księstwo, które łączyła zmienna podległość wasalna wobec różnych sąsiadów. Po wygaśnięciu panującego rodu Gryfitów, drogą sukcesji lub kupna, zostało przyłączone do ościennych państw, aby ostatecznie ulec scaleniu w obrębie Królestwa Pruskiego po kongresie wiedeńskim w 1815 roku.

Niemniej, gdy po klęsce III Rzeszy w 1945 roku tereny te przyznano Polsce, po zadekretowaniu „odwiecznej polskości” tych ziem, zastosowano tu te same zabiegi co w przypadku repolonizacji obszarów wchodzących w granice państwa polskiego przed rozbiorami i przed II wojną światową (patrz np. Zarządzenie 1946). Z iście dekolonizacyjną pieczołowitością „oznaczono teren” i starano się zacierać ślady niemieckości, nadając miejscom nowe polskie nazwy oraz zastępując niemieckie polskimi symbolami, a także przepisując na nowo przeszłość w celu wyeksponowania historycznych związków z "macierzą" i uzasadnienia „sprawiedliwości dziejowej”. Dokonano także „orientalizacji” i „egzotyzacji” niemieckości i Niemców, rozwijając w kulturze publicznej narracje o ich „tysiącletniej wrogości”" i „zdradzieckiej naturze”9 (Strauchold 2012: 2 i dalsze). Było to w pew-

8 Interesujące, że również współcześnie politycy posługują się tego rodzaju zwrotami. W 2013 roku, w Lesznie, podczas obchodów 95. rocznicy wybuchu powstania wielkopolskiego, prezydent tego miasta Tomasz Malepszy stwierdził, iż „zryw Wielkopolan przeszedł do historii jako jedna z nielicznych udanych prób odzyskania wolności. «- Zwyciężony został odwieczny, ponad tysiącletni wróg Rzeczpospolitej, Niemcy - mówił - Cesarstwo Pruskie, które brało udział we wszystkich trzech rozbiorach Polski»" (cyt. za: Radio elka.pl). Znamiennie, iż Leszno było siedzibą silnego garnizonu niemieckiego i nie zostało zdobyte przez powstańców, lecz przyznane Polsce w wyniku ustaleń konferencji wersalskiej.

9 Proces historycznego kształtowania się w polskiej kulturze publicznej zmiennych wyobrażeń na temat Niemiec i Niemców do 1939 r. obszernie omówił Wojciech Wrzesiński (1992). „Egzotyzację” rozumiem tu jako zabiegi zmierzające do wykazania braku swojskości Innego i jego „dziwaczności”, „orientalizacja” zaś to złożony proces utrwalania w świadomości tych cech Innego, które sytuują go jako immanentnie nieprzystosowanego i niezasługującego na podmiotowe traktowanie, a zatem jako tego, kogo powinno się zastąpić kimś o pożądanej charakterystyce. W przypadku Niemców podkreślano ich wrogość i imperialne ciągoty, które miały się uwidaczniać w dziejach. Podkreślano tym samym jeden z elementów wizerunku Niemców, który - jako punkt odniesienia - miał bezpośredni związek z procesami tworzenia polskiej tożsamości w kontekście zaborów i oku- 
nym sensie zwykłym odwróceniem retoryki stosowanej przez duchowych przodków ideologii Lebensraum (np. Kossina 1912; Haushofer 1939), którzy uzasadniali prawo Niemiec do rozmaitych terenów istnieniem tam osadnictwa niemieckiego (Walsh 1948, za: Dalby et. al. 2003: 40-41), lub też prehistoryczną obecnością jakichkolwiek Germanów. W polskiej kulturze publicznej stosowano te same zabiegi ${ }^{10}$ (np. Kostrzewski 1961), przy czym Polacy znienacka okazali się „spadkobiercami” na przykład Wieletów (np. Kozierowski 1934) ${ }^{11}$. Co równie ciekawe, teoretycznych ram dla polskich historycystycznych narracji naukowych dostarczały czasem opracowania niemieckie z lat 1933-1945 (zob. np. Łowmiański 1967).

W przypadku wszystkich trzech omawianych społeczeństw mamy do czynienia $\mathrm{z}$ sytuacją pokolonizacyjną, w której na różny sposób olbrzymią rolę odgrywają nacjonalizmy wytworzone $\mathrm{w}$ warunkach i na skutek podporządkowania wobec odbieranych jako zewnętrzne potęg lub pod olbrzymim merytorycznym wpływem ich kultury. W interakcji tej przede wszystkim powstały etniczności polityczne, tu: fidżyjska, indofidżyjska, jamajska, polska. Na Fidżi i na Jamajce były

pacji hitlerowskiej. Edward Said pisał o wizerunku islamu w Europie „[b]o też nie bez powodu stał się islam - widziany jako horda znienawidzonych barbarzyńców - symbolem terroru, dewastacji, zła. W pamięci Europy pozostawił islam trwałą bliznę. Aż do końca XVII wieku «osmańskie niebezpieczeństwo» wisiało nad Europą, stanowiąc permanentne zagrożenie dla całej cywilizacji chrześcijańskiej" (Said 1991: 101). W tej perspektywie, łączącej pogardę i podziw, lekceważenie i strach, Inny, który był odwiecznym wrogiem, nawet pokonany i względnie oswojony, wymaga nieufności i kontroli, a także powinien być osłabiany, gdyż pewnego dnia może znów ujawnić swe wrodzone skłonności.

10 Piotr Eberhardt w licznych publikacjach (np. Eberhardt 2004, 2006, 2013) omawia okoliczności i źródła dyskursu na temat kształtu geopolitycznego granic Polski po II wojnie światowej i jego odbicia w kartografii, choć wydaje się, że dość bezkrytycznie traktuje ustalenia historyczne dotyczące zasięgu terytorialnego państwa Piastów i jego „granic”, ulegając tym samym „narodowemu duchowi historii" (zob. Eberhardt 2013: 270).

11 Ks. Stanisław Dołęga Kozierowski ujął to obrazowo w Przedmowie do Atlasu nazw geograficznych Słowiańszczyzny Zachodniej: „Sądzę, że najpiękniejszy po sobie pomnik kultury duchowej i materialnej zostawili nasi przodkowie i pobratymcy w tysiącach nazw geograficznych i topograficznych na ziemiach swoich. Niemal każdy skrawek pola o charakterystycznych znamionach, każda niwa zroszona ich potem i krwią, lasy, puszcze i święte gaje, dąbrowy, bagna, ostrowy, góry i pagórki, jeziora i tonie, rzeki, strumienie i brody świadczą o prastarych dziedzicach, lechickich wojach i panach, ratajach i rybitwach, których szczątki z szarym zmieszały się prochem - wszystko to otrzymało w nazwach piętno własności rasowej. Daleko na zachód, hen do Menu i Soławy, za Łabą, do brzegów Morza Północnego i Egidory olbrzymią płacheć ziemi zajmowali niegdyś Słowianie rozmaitych rodów i szczepów, bliscy nam pochodzeniem i językiem, w nazwach przekazali nam wspominki, nie nieme jak kamień, lecz zrozumiałe i głośno świadczące: Byliśmy! Dwa światy, germański i słowiański, w wiekowych zapasach i zmaganiach toczyły boje o te krainy, aż ostatnia Słowianka na Rugji w XV w. zeszła do mogiły, ostatni Słowianin w Hanowerskiem za Łabą pisał w XVIII w. testament rodzimego języka, a za naszych prawie czasów zamilkł rybak kaszubski koło Słupska i rolnik śląski pod Oleśnicą. Przybysze i nowacy z zachodu, biorąc pola w posiadanie prawem miecza lub umowy, bądź usuwali zupełnie, bądź zmieniali nazwy słyszane z ust tubylców. Przepadło wskutek tego mnóstwo, inne znów niezrozumiane przez przychodźców i wkońcu przez dziedziców samych zniekształcono nieraz do niepoznania" (Kozierowski 1934: 3 [pisownia oryginalna]). 
one efektem odgórnego włączania ludzi na podstawie „podobieństwa geograficznego", polegającego na skojarzeniu fenotypu z pochodzeniem, do specjalnie utworzonych homogenizujących kategorii administracyjno-spisowych określających status tak stworzonych grup w etnorasowych hierarchiach władzy. Akceptacja tak przypisanych ról nie odbywała się bezkonfliktowo i bezkrytycznie. Część społeczności zachodniego Fidżi Brytyjczycy musieli przekonać do nowego ładu fizycznym podbojem. Grupa indofidżyjska powstała jako kategoria obejmująca pierwotnie girmiytis - pracowników kontraktowych pochodzących z różnorodnych obszarów kolonialnych Indii (a także Afganistanu), należących do różnych kast, grup etnicznych, językowych i wyznających różne religie (Lal 1992). Narzucony status i wspólnota losów w ramach tak zwanej kultury plantacyjnej spowodowały, iż większość z tych ludzi zaakceptowała pozycję „Indusa”, choć niektórym wydawało się to śmieszne. Dla porównania na Mauritiusie wielu ludzi, których przodkowie przybyli z Indii Południowych, odrzuca bycie Indusami, afirmując swoją tamilskość (Eriksen 1988).

W tym kontekście jamajskość stanowi wypadkową zróżnicowanego procesu kreolizacji, której najważniejszym wspólnym mianownikiem jest pośrednia afrykańskość. Kolonialny system stratyfikacji rasowej i etnorasowej rezerwował odrębne nazwy dla funkcjonujących w jego ramach najliczniejszych kategorii: białych, kolorowych (brązowych) i czarnych, przy czym istotną rolę odgrywała świadomość pochodzenia określonego przez narzucone przez Europejczyków kategorie geograficzne. Tak oto biali pochodzili z Europy, czarni z Afryki, kolorowi byli mieszanką dwóch pierwszych grup ${ }^{12}$ (w późniejszym czasie uzupełniono ten system o grupy napływające $\mathrm{z}$ Indii i Chin, przy czym tu pojawił się oczywisty problem poznawczy o naturze rasistowskiej, gdyż nie utworzono dla nich wspólnej kategorii „azjatyckiej”"13). Każda domieszka „czarnej krwi” powodowała przynależność do grupy „kolorowej”. Niemniej filiacja do tej lub „czarnej” grupy oznaczała także uczestnictwo w grupie kreolskiej - różnorodnej mieszance ludzi pochodzących z rozmaitych grup etnojęzykowych Afryki Zachodniej, która $\mathrm{w}$ ramach wspomnianego powyżej statusu podrzędnego wobec białych stanowiła przytłaczającą większość populacji Jamajki. Ponadto, jak zauważa Stuart Hall, biali, Europejczycy, mogli wskazać, skąd przybyli ich przodkowie, natomiast potomkowie niewolników, choć ogólnie mogą zakładać, że pochodzą z Afryki

12 Przed zniesieniem niewolnictwa dziecko białego i niewolnicy rodziło się jako niewolnik. W dobrym tonie było wykupienie z niewoli takiego dziecka lub przyznanie mu wolności (Sherlock, Bennett 1998: 55).

13 Problem ten pojawiał się na wielu obszarach administracyjnych Imperium Brytyjskiego, gdzie zwykle Chińczycy i Indusi występowali pod tymi nazwami, a gdy tworzono kategorię „Azjaci”, wpisywano do niej jedną z tych grup, co oddziaływało na świadomość ludzi. Na Fidżi spotkałem się z wypowiedzią Induski imieniem Rani, zaniepokojonej niekontrolowaną jej zdaniem migracją z Chin: „They should do something with this Asian migration” (Rani, 07.06.2004, za: Kaczmarek 2008: 140). Natomiast Yasmin Hai, Brytyjka pochodzenia pakistańskiego, używa w swej książce terminu Asia jako określenia dotyczącego własnej grupy oraz ludzi pochodzących z Indii (Hai 2009). 
Zachodniej, to z licznych powodów nie mieliby możliwości tam „powrócić”, co wpływa na intensywność ich „diasporycznej”, kreolskiej tożsamości związanej z Karaibami (Hall 2008: 175 i n.).

Prowadząc na podobnym poziomie ogólności analizę kolonizowania wiedzy, a zatem narzucania jej określonego porządku zgodnego z wyobrażeniami grupy dominującej politycznie, można postawić tezę, że w przypadku obszarów Polski dopiero w obliczu rozbiorów przez Prusy, Rosję i Austrię oraz już pod kolonialnym panowaniem tych państw zaczęto śmielej mówić o narodzie polskim jako zbiorze mieszkańców tych ziem (Konstytucja 3 Maja 1791). Stało się tak w znacznej mierze w wyniku potrzeby zarządzania wielokulturowym społeczeństwem w sposób uznawany za nowoczesny i przeprowadzenia „klasyfikacji posiadanych zasobów”, tak by nie przegrać wyścigu z otaczającymi państwami, które tego rodzaju porządki już wprowadzały. Trendy w tym okresie, a mowa o przełomie XVIII i XIX wieku, wciąż wyznaczały „absolutyzmy oświecone”, których najważniejszym narzędziem była administracja organizowana zgodnie z kanonami „arytmetyki politycznej" (Petty 1690) i Staatswissenschaft (Achenwall 1749), czyli wczesnej statystyki rozumianej jako zarządzanie danymi na potrzeby państwa. Proces ten zbiegł się jednak z powstawaniem „etnograficznego archiwum” i wzrostem zainteresowania zróżnicowaniem kulturowym oraz etnicznym w kontekście narodów i narodowości (Beiser 2016: 245; zob. też Dirks 2002) ${ }^{14}$.

Omawiane w tym eseju obszary stanowiły kiedyś terytoria podporządkowane „zewnętrznym” państwom, co jest często motywem dyskusji w ich kulturze publicznej. Jednak mam wrażenie, że motyw ten jest o wiele rzadziej wykorzystywany jako klucz do całościowego wyjaśniania obecnych relacji społecznych i ekonomicznych przez członków społeczności lokalnych w ich codziennym życiu. Świadomość ta w narracjach większości osób, z którymi rozmawiałem, przejawia się w oddolnych obserwacjach „mimikry” (Bhabha 2008), co może jednak świadczyć zarówno o ich spostrzegawczości, jak i o tym, że postkolonialny i postsocjalistyczny zasób językowy zakorzenił się w zestawie krytycznych argumentów i inwektyw. Moi rozmówcy nie używali oczywiście słowa „mimikra”, ale wskazywali na reprodukowanie kolonialnych postaw - zarówno „władców”, jak „poddanych” - w zdekolonizowanych społeczeństwach oraz krytykowali mentalność przełożonych, podwładnych lub współpracowników, z których nie byli zadowoleni. Obiektem „postkolonialnych" pretensji bywały także przykłady złego działania instytucji publicznych, czy to rządowych, czy samorządowych, oskarżanych przez moich rozmówców o „fasadowość” („istnieją tylko dlatego, że wymaga tego UE”, albo „chcieli, by działało to jak w krajach rozwiniętych, ale nie potrafią tego obsługiwać" - tu, co ciekawe, podobne uwagi dotyczyły działania uniwersytetów w Polsce i na Jamajce ${ }^{15}$ ). Jednak

14 Frederick C. Beiser prowadzi dyskusję na ten temat w ramach rozważań o stosunku Herdera do kwestii żydowskiej.

15 Na Jamajce partnerka badawcza powiedziała mi o uniwersytecie: „It was funded because it existed in England, but they still don't know what they have it for". W Polsce natomiast wspomniana 
większość osób, z którymi rozmawiałem na temat kłopotów wynikających z działalności instytucji publicznych, wskazywała na bieżące i strukturalne problemy finansowe, nieuprzejmość urzędników, brak przejrzystości procedur i ich niesprawność, a także zły stan stanowionego prawa i nieudolność polityków. Bardzo niewielu rozmówców odnosiło się do szerszego kontekstu historycznego, a dotyczyło to głównie wchodzenia współczesnych elit władzy i gospodarczych w role tych dawnych - kolonialnych i socjalistycznych - i dalszego przedmiotowego lub peryferyjnego traktowania „Zwykłych ludzi”. W Polsce i na Jamajce, gdzie społeczeństwa są obecnie stosunkowo homogeniczne kulturowo, praktycznie wszyscy moi rozmówcy wiązali relatywnie niskie zarobki z zapóźnieniami rozwojowymi i eksploatacją gospodarczą w okresie podporządkowania cudzym rządom. Większość wyrażała jednak przekonanie, że gdyby rządzący i elity gospodarcze ich krajów nie popełnili błędów, nie tracili energii na wewnętrzną walkę polityczną oraz nie wprowadzali sztucznych mechanizmów przeciwdziałających wzrostowi wynagrodzeń, to kontrast z sytuacją materialną ludzi żyjących w krajach rozwiniętych byłby zdecydowanie mniejszy. $\mathrm{Na}$ Fidżi, gdzie występują dość znaczące podziały etniczne dotyczące dużych grup mieszkańców, sporo osób wskazywało także na winę kulturowych Innych. Niemniej odniosłem wrażenie, że w każdym z tych krajów wśród osób, które podejmowały ze mną dyskusję na temat sytuacji społeczno-gospodarczej i statusu społecznego, przeważała tendencja do poszukiwania kulturowych, a nie ekonomicznych wyjaśnień obecnego stanu. Ponadto koncentrowały się one bardziej na analizowaniu sytuacji geopolitycznej, społecznej i gospodarczej w perspektywie historii po uzyskaniu suwerenności niż czasów bezpośredniej zależności politycznej od państw trzecich.

Takie podejścia oraz upływ czasu osłabiają rangę przemian dekolonizacyjnych i transformacji postsocjalistycznej w oczach wielu członków społeczności lokalnych niezależnie od ich wykształcenia i pozycji społecznej oraz pozwalają relatywizować bilans płynących z nich zysków i strat. Na przykład na Fidżi wielu moich partnerów badawczych twierdziło, że - podobnie jak w czasach kolonialnych - głównymi beneficjentami wszelkich zmian są wodzowie i gospodarcze, europejskie i indyjskie, elity, status „zwykłych Indusów i Fidżyjczyków” nie uległ zaś większej poprawie. $Z$ kolei przedstawiciele grupy indofidżyjskiej (a także niektórzy Fidżyjczycy) niejednokrotnie zauważali, że rdzenni Fidżyjczycy po prostu zajęli miejsce Europejczyków, zachowując nawet system rządów pośrednich wobec przedstawicieli własnej grupy, gdy Indusów wciąż nie traktuje się jako pełnoprawnych obywateli. Mieszkańcy obszarów wiejskich na Jamajce często wskazywali, że tak jak w czasach kolonialnych rząd się nimi nie interesuje i dalej żyją w biedzie, pozbawieni organizacyjnego, politycznego i ekonomicznego wsparcia. W okolicach Szczecina z kolei wielu partnerów badawczych narzekało, że w PRL zaniedbywano Pomorze Zachodnie, gdyż obawiano się, że powróci do Niemiec, a w wolnej Polsce „tradycyjny” brak pomocy z „centrali” przyczynia się do za-

uwaga dotyczyła szeregu sfer działających w sposób niesatysfakcjonujący dla rozmówcy, wśród których wymienił nowoczesne systemy sterowania ruchem ulicznym, uniwersytety i demokrację. 
przepaszczania szans rozwoju regionu. Zgodnie z tymi, z oczywistych względów subiektywnymi, narracjami, Polska (centrala) wciąż nie jest wystarczająco zaangażowana $\mathrm{w}$ zintegrowanie Ziem Odzyskanych $\mathrm{w}$ ramach swojego terytorium (nawet systemu transportowego), a większe zainteresowanie tymi aspektami często okazują Niemcy. Powtarzane są też argumenty o homo sovieticus, jednak uzupełniane wskazaniami na „mentalność pańszczyźnianą”, oraz oskarżenia o „partyjniactwo" tłumaczone obecnie powiązaniami "mafijno-gospodarczymi”, a nie charakterem minionego ustroju.

Niemniej znaczenie nadawane dawnej podległości nie maleje wśród aktorów kultury publicznej, spośród których wielu rozwija na tym tle esencjalizujące narracje legitymizujące odgórnie relacje władzy lub je krytykujące bądź też - również z perspektywy odgórnej - wyjaśniające kondycję społeczną. Na Fidżi wśród tak zwanych konserwatystów funkcjonują często wyrażane poglądy, iż państwo powinno kultywować tradycje rdzennie fidżyjskie i pielęgnować wdrożony przez Brytyjczyków system neotradycyjny (zob. Macnaught 1982; Kaczmarek 2011) w powiązaniu z dominacją rdzennych Fidżyjczyków i chrześcijaństwa, ale z drugiej strony artykułowane jest stanowisko, że czas kolonializmu się skończył i nikt nie będzie mówił Fidżyjczykom, jak się mają rządzić w swoim kraju (wobec nacisków wspólnoty międzynarodowej potępiającej kolejne rządzące junty za ignorowanie standardów demokratycznych oraz gwałcenie praw człowieka). Kolonialistów obarcza się też odpowiedzialnością za sprowadzenie Indusów, podporządkowanie zachodniej części kraju wschodniej, czyli za spowodowanie istniejących dziś konfliktów. Na Jamajce w kulturze publicznej kwitnie afirmacja afrykańskiego dziedzictwa powiązana $\mathrm{z}$ wypominaniem kolonizatorom niewolnictwa i pielęgnowaniem nierówności społeczno-rasowej po jego zniesieniu. Dawnemu niewolnictwu i późniejszej niedoli czarnych Jamajczyków przypisuje się często odpowiedzialność za rozmaite współczesne „dysfunkcje” społeczeństwa wyspy, od sytuacji rodzinnej, przez przestępczość, po ekonomiczne zacofanie. W Polsce zaś podporządkowanie różnym państwom zaborczym poszczególnych terytoriów kraju nierzadko wiąże się z odmiennością w ich gospodarczym rozwoju, preferencjach wyborczych, stosunku do integracji europejskiej i do sąsiednich narodów (np. Czubkowska 2010), w kondycji miast i wsi oraz społeczeństwa obywatelskiego, a nawet wyjaśnia się tak stosunek do kobiet i ich - im bardziej na wschód, tym większą - zależność awansu społecznego od atrakcyjności cielesnej (Szlendak w: „Wysokie Obcasy” 2012).

„Postkolonializm” i „postsocjalizm”, będąc istotnymi aspektami naukowej interpretacji relacji społecznych, zostają „zubożone” na poziomie dyskursów kultury publicznej i stopniowo tracą na znaczeniu przy analizach prowadzonych z perspektywy oddolnej. Ulegają postępującemu przewartościowaniu i degradacji do roli „Zwyczajowych” elementów zestawu wyobrażeń społecznych, ustępując miejsca symbolom bardziej aktualnym z punktu widzenia lokalnych społeczności. Stają się komunałami, a dla młodszych pokoleń - mglistymi wyobrażeniami. 
W narracjach większości tak zwanych zwykłych ludzi, z którymi na ten temat rozmawiałem, okres "cudzego panowania”, czy też obecności „dawnych panów”, pojawia się głównie jako „stara historia”, która - niczym Levi-Straussowski mitem - może zostać podstawiona jako element wielu opowieści lub wyjaśnień obecnej sytuacji, ale sposób jej przedstawiania ogranicza się do utrwalonych reprezentacji - pewnego rodzaju schematów semantycznych, dyżurnych komunałów utrwalonych w reżimach tożsamości, na przykład przez system edukacyjny czy ideologię głoszoną $\mathrm{w}$ formie narracji konstruowanych i pielęgnowanych przez elity (zob. Bloch 2011).

Jednocześnie używane do ich odgórnej analizy retoryka i terminologia, w znacznej części wytworzone w dyskursach XIX-wiecznej i wcześniejszej kultury publicznej (zob. Bystroń 1995 [1935]; Said 1991; Cohn 1996; Anderson 1997; Hobsbawm, Ranger 2008), ulegają popularyzacji i „demokratyzacji” oraz znajdują bieżące zastosowanie w lokalnych dyskursach i praktykach społecznych (zob. Buchowski 2008; Bill 2014 a i b; Dirks 2002; Kaczmarek 2014). Nie skończyły się jeszcze dyskusje o tym, czym był i jest kolonializm oraz jakie były i są jego konsekwencje w skali globalnej i lokalnej. Na dobrą sprawę nie umiemy powiedzieć, że już się skończył. Pomimo - oraz na skutek - transformacji ram funkcjonowania i wymiany rządzących elit wciąż trwa jako nie zawsze dobrze zawoalowana, a nieraz otwarta kontynuacja pewnego systemu wartości i metod sprawowania kontroli gospodarczo-politycznej nie tylko nad zewnętrznymi terytoriami i społeczeństwami zależnymi, ale przede wszystkim - nad własnym społeczeństwem. Czymże innym są artykułowane przez polityków marzenia o „odzyskaniu świetności” i „utraconej dumy”? W tym sensie współczesna mutacja postsocjalizmu, „wynagradzania krzywd” doznanych „od komunistów” oraz wyrządzonych „przez komunistów”, w tym „zdrady Zachodu” - widoczna przede wszystkim w polityce Węgier i Polski - jest znakomitym polem do analiz prowadzonych w optyce teorii postkolonialnej, obok Turcji prezydenta Erdogana, Indii premiera Modiego czy Wenezueli Cháveza i Maduro. Okazuje się, że bardzo podobne motywacje artykułuje również prezydent USA oraz przedstawiciele dążącej do wyjścia z Unii Europejskiej części brytyjskiej klasy politycznej.

XVIII-, XIX- i XX-wieczna kolonizacja stała się procesem globalnym, którego konsekwencje dotyczą zarówno kolonii, jak i państw-centrów kolonialnych. Przez okres ponad 200 lat zmieniały się relacje społeczne, powstawały i przetwarzały się nowe etniczności i narodowości, z których pewne już nie istnieją, a inne nie przypominają wyjściowego kształtu. Bywało i bywa, że państwa i społeczeństwa, dawniej podporządkowane, zależne, które wyzwoliły się „spod jarzma” w atmosferze walki o wolność i równość, realizowały imperialne projekty (najznamienitsze przykłady to USA i Chiny). Inne - na przykład Wielka Brytania (choćby British Commonwealth), Francja, Hiszpania - wykorzystując wytworzone w dobie kolonializmu sieci powiązań polityczno-ekonomiczno-kulturowych i językowych, czy wręcz nadużywając ich, odgrywają istotną rolę w życiu dawnych kolonii, co nie 
zawsze spotyka się z bezwarunkową akceptacją społeczeństw tych ostatnich. Wystarczy spojrzeć na skład rady bezpieczeństwa ONZ, żeby zobaczyć, kto „rządzi światem" - dwie dawne kolonialne superpotęgi (brakuje Hiszpanii, która w dobie powoływania tego ciała trwała w izolacji rządów frankistowskich), Rosja, dawniej ZSRR, Chiny - mocarstwo o imperialnej tradycji sięgającej tysiące lat wstecz, które już w XX wieku pod hasłem „wyzwalania” anektowały ościenne państwa i terytoria, i USA - dawna kolonia, która, gdy tylko uzyskała niepodległość, wykazała dużą energię w powiększaniu swojego terytorium kosztem sąsiadów i uczestniczeniu w wyścigu kolonialnym, polując na ochłapy pozostawiane przez innych i nie wahając się zajmować niepodległych krajów lub podporządkowywać ich, gdy wymagała tego „racja stanu”. Belgia, Holandia, Portugalia, Niemcy, Japonia, nawet maleńka Dania i inne kraje europejskie czerpały lub dalej czerpią korzyści polityczne, ekonomiczne czy choćby psychologiczne, a czasem doświadczały kłopotów w związku z eksploatacją odległych krajów i społeczeństw, nad którymi sprawowały choćby krótkotrwałą kontrolę. Do listy tej można dodać Australię, Nową Zelandię (Wyspy Cooka), Kanadę, Rosję, Indonezję, Indie, wiele krajów południowoamerykańskich, które jako pewnego rodzaju spadkobiercy dawnych kolonialnych imperiów przejęły kontrolę nad niektórymi terytoriami zależnymi lub otrzymały w spuściźnie swój obecny kształt geograficzno-społeczny i związaną z tym potrzebę zarządzania różnorodnością.

W tym kontekście władzy możemy rozpatrywać radziecko-centryczny socjalizm jako formę kontroli kolonialnej realizowanej za pomocą rządów pośrednich (w schyłkowym okresie imperium Brytyjczycy także często rekrutowali gubernatorów spośród ludności rdzennej). Gdy studiujemy ustroje prawne tych państw i tych, dawniej od nich zależnych, które nader często tworzono na podwalinach praw kolonialnych, możemy dostrzec wiele kontynuacji. Podobnie genezy obecnego prawa międzynarodowego, jak również dzielenia świata na strefy wpływów przy konferencyjnych stołach można się dopatrywać w praktykach kongresu wiedeńskiego z lat 1814-1815 (tzw. koncertu mocarstw), w trakcie którego z jednej strony potępiono niewolnictwo i sformułowano zasady protokołu dyplomatycznego, a z drugiej na niespotykaną dotąd skalę przesuwano terytoria i państwa $\mathrm{z}$ rąk jednych władców do rąk drugich.

Te wyobrażenia często towarzyszą dyskusji o postkolonialności i są moim zdaniem cechą charakterystyczną postkolonializmu - różnorodnego intelektualnego nurtu analizy konsekwencji sytuacji zależnościowej czy podległościowej obejmującej zarówno centra władzy, tak zwane metropolie, jak i terytoria podporządkowane od momentu zaistnienia podległości do czasów współczesnych, gdy wiele z nich cieszy się formalną niezawisłością.

Stąd zrozumiała jest postawa badaczy postkolonialności (np. krytyków postkolonialnych), którzy tropią konsekwencje zależności na rozmaitych polach i próbują wzniecać wywołujące refleksje, a niekiedy kontrowersje, dyskusje dotyczące następstw dominacji i podporządkowań ujawniających się w dawnym i dzisiej- 
szym świecie. Trudniejsza do zrozumienia jest historycystyczna postawa piewców wyższości pewnych „cywilizacji” lub narodów i ich legitymacji do dominacji nad innymi (czy to politycznej, czy kulturowej, czy też ekonomicznej), na przykład w granicach stref wpływu lub państw. Co niezwykle istotne, jedni i drudzy często tkwią w pułapce obowiązujących deterministycznych dyskursów i w ten sposób je odtwarzają i utrzymują przy życiu, choć to właśnie walce z takimi metanarracjami poświęcona była część klasycznych opracowań z kręgu refleksji postkolonialnej.

Oczywiście echa wielkich odgórnych metanarracji są czasem (bywa, że nawet często) obecne w toczonych rozmowach, ludzie są poddawani „reżimom tożsamości" - chodzą do szkól, świątyń, czytają prasę bądź oglądają telewizję, w których serwowane są im gotowe wyjaśnienia (np. część Fidżyjczyków wierzyła, że ich przodkowie wywodzą się prosto z okolic jeziora Tanganika w Afryce, gdyż pewni misjonarze im powiedzieli, że występują tam podobne nazwy geograficzne, inni, że ranga lineażu wodzowskiego pochodzi od Boga, Jahwe, a ja sam często się zastanawiam nad wpływem, jaki wywarła XIX-wieczna wielkopolska praca u podstaw na sposób funkcjonowania samorządu terytorialnego w Poznaniu, czy też jak oddziaływał fakt, że w Szczecinie zamieszkują wnukowie osadników i „repatriantów", na ich stosunek do poniemieckiej przestrzeni). To nie pozostaje bez wpływu na praktyki, sposoby myślenia i deklaracje (zob. Kaczmarek, Parowicz 2013; Kaczmarek, Ładykowski 2012). Niemniej w terenie widać również, że większość codziennych trosk ludzi to zdecydowanie bardziej złożone i mniej abstrakcyjne problemy.

Wielu Jamajczyków podchodzi relacyjnie do problemów swojego społeczeństwa - wiedzą, że ich przodkowie byli na przykład niewolnikami albo pracowali $\mathrm{w}$ administracji kolonialnej oraz że ustrój państwa został wynegocjowany w okresie zimnowojennej dekolonizacji. Niemniej mają pretensje do współczesnego rządu o brak wrażliwości i dbałości o potrzeby zwykłych ludzi, a także oskarżają kraje rozwinięte o nadmiernie restrykcyjną politykę wizową, która uniemożliwia wielu uczciwym obywatelom Jamajki rozpoczęcie lub kontynuację legalnego zarobkowania za granicą.

Sporo mieszkańców okolic Szczecina, którzy przeprowadzili się do Niemiec, utyskuje na relacje cenowe, system szkolnictwa, sytuację mieszkaniową, złe funkcjonowanie samorządu w ich polskich miejscowościach, wskazując, że najbiedniejsze gminy w Niemczech, do których się przenieśli, bardziej dbają o ich potrzeby, niż miało to miejsce w Polsce (nawet w odniesieniu do tych polskich samorządów, których dochód jest wyższy niż w niemieckich jednostkach terytorialnych, w których mieszkają).

W interpretacjach naukowych, wyjaśniając współczesne zjawiska społecznokulturowe, warto zwracać uwagę na procesy i uwarunkowania, które wpływały na ich kształtowanie. A przy tym ostrzegać przed nadmiernie upraszczającym, deterministycznym myśleniem o ludziach przedmiotach należących do z góry znanych kategorii, którzy w zuniformizowany i możliwy do przewidzenia sposób 
reagują na bodźce ${ }^{16}$. Do takich skrajności może też prowadzić wspierany autorytetem naukowym i esencjalizujący dyskurs kultury publicznej, na przykład klasowy (Gdula 2017), rasowy, płciowy, religijny (Bortkiewicz 2014; zob, Jakubowska 2014; Strutyński 2014, Zimmermann 2006; Ritz 1999). Pochodzącymi stąd komunałami posługują się następnie niektórzy politycy oferujący łatwe recepty albo tłumaczący się z niepowodzeń. Uwielbiają się też do nich odwoływać ci publicyści, którzy starają się pozycjonować swoich rozmówców czy przedmioty opisu na spolaryzowanych stanowiskach. W takich praktykach, jak wykazuje Stanley Bill (2014a), mają swe źródło polskie spory ideologiczne związane z wykorzystaniem „teorii postkolonialnej”.

Używajmy ostrożnie pojęć, które często implikują więcej, niż chcemy powiedzieć w konkretnym przypadku. I korzystajmy z tego, co najlepsze dla nauki w rozbudowanych wokół tych pojęć dyskursach - krytycznych perspektywach, które sprawiają, że wciąż możemy znaleźć i zaproponować coś nowego. Uprawianie nauk społecznych i humanistycznych może być pasjonujące. Może też jednak przerażać, gdy rzucane przez naukowców słowa zmieniają sens i stają się instrumentami służącymi do podporządkowywania ludzi ideom, przed których zgubnym działaniem przestrzegamy.

\section{Bibliografia}

Achenwall G.

1749 Abriß der neuen Staatswissenschaft der vornehmen Europäischen Reiche und Republiken, Göttingen.

Anderson B.

1997 Wspólnoty wyobrażone. Rozważania o źródłach i rozprzestrzenianiu się nacjonali$z m u$, Warszawa-Kraków.

Beiser F.C.

2016 Herder and the Jewish Question, w: A. Waldow, N. DeSouza (eds.), Herder: Philospophy and Anthropology, Oxford, s. 240-256.

Bhabha H.K.

2008, Mimikra i ludzie. O dwuznaczności dyskursu kolonialnego, przeł. T. Dobrogoszcz, „Literatura na Świecie”, nr 1-2.

Bill S.

2014a Seeking the Authentic: Polish Culture and the Nature of Postcolonial Theory, „Nonsite”.

2014b W poszukiwaniu autentyczności: kultura polska i natura teorii postkolonialnej, przeł.

P. Juskowiak, „Praktyka Teoretyczna” nr 1(11), http://www.praktykateoretyczna.pl/ PT_nr11_2014_Socjologia_literatury/05.Bill.pdf (dostęp: 01.11.2014).

16 Wiele omówień badań naukowych dostępnych w opiniotwórczych mediach wykazuje przejawy takiego myślenia na temat biologicznego funkcjonowania ludzi ze strony naukowców lub nie dość refleksyjnych popularyzatorów nauki, np. Moskal 2012; Burda 2013; Woźniak 2015, 2017; Łukasik 2017; Kossobudzka 2018. 
Bloch N.

2011 Urodzeni uchodźcy. Tożsamość pokolenia młodych Tybetańczyków w Indiach, Monografie Fundacji na rzecz Nauki Polskiej, Wrocław.

Bortkiewicz P.

2014 Historia jednego wykładu, czyli gender zdemaskowany, Warszawa.

Buchowski M.

2008 Widmo orientalizmu w Europie. Od egzotycznego Innego do napiętnowania swojego, „Recykling Idei”, nr 10, wiosna/lato, s. 98-107.

2013 Neoliberalizm w Europie Środkowej - magia, religia czy nauka? „Poznańskie Studia Slawistyczne" nr 4, s. 29-41.

Burda K.

2013 Sekret czarnoskórych sprinterów, http://www.newsweek.pl/wiedza/nauka/sekretczarnoskorych-sprinterow,107585,1,1.html (dostęp: 04.09.2013).

Buruma I., Margalit A.

2005 Okcydentalizm. Zachód w oczach wrogów, przeł. A. Lipszyc, Kraków.

Bystroń J.S.

1995 [1935] Megalomania narodowa, Warszawa.

Chakrabarty D.

2011 Prowincjonalizacja Europy. Myśl postkolonialna $i$ różnica historyczna, przeł.

D. Kołodziejczyk, T. Dobrogoszcz, E. Domańska, Poznań.

Cohn B.S.

1996 Colonialsm and Its Forms of Knowledge: The British in India, Princeton.

Czubkowska S.

2010 To nie wybory nas podzielity, ale zaborcy, „Dziennik.pl”, 5 lipca, http://wiadomosci.dziennik.pl/polityka/artykuly/280908,to-nie-wybory-nas-podzielily-ale-zaborcy. html (dostęp: 10.03.2017).

Dalby S., Routledge P., Ó Tuathail G.

2003 The Geopolitics Reader, London-New York.

Dirks N.B.

2002 Castes of Mind: Colonialism and the Making of Modern India, New Delhi.

Do Rzeczy

2018 Polska nie będzie płaciła podatku od niemieckich zbrodni: z Jarosławem Kaczyńskim, prezesem Prawa i Sprawiedliwości, rozmawia Kamila Baranowska, „Do Rzeczy”, nr 7/260, 12-18 lutego, s. 16-20.

Dz.U. 2018 poz. 369

2018 Ustawa z dnia 26 stycznia 2018 r. o zmianie ustawy o Instytucie Pamięci Narodowej - Komisji Ścigania Zbrodni przeciwko Narodowi Polskiemu, ustawy o grobach i cmentarzach wojennych, ustawy o muzeach oraz ustawy o odpowiedzialności podmiotów zbiorowych za czyny zabronione pod groźba kary.

Dz.U. 1998 nr 155 poz. 1016

1998 Ustawa z dnia 18 grudnia 1998 r. o Instytucie Pamięci Narodowej - Komisji Ścigania Zbrodni przeciwko Narodowi Polskiemu (opracowano na podstawie: t.j. Dz. U. z 2016 r. poz. 1575 , z 2018 r. poz. 5).

Eberhardt P.

2004 Polska i jej granice. Z historii polskiej geografii politycznej, Lublin.

2006 Twórcy polskiej geopolityki, Kraków.

2013 Linia Odry i Nysy Łużyckiej, jako zachodnia granica Polski - postulaty i urzeczywistnienie, „Prace Geograficzne”, nr 218, s. 265-305. 
Eriksen T.H.

1988 Communicating Cultural Difference and Identity: Ethnicity and Nationalism in Mauritius, Oslo.

Garvey A. (ed.)

1923 Philosophy and Opinions of Marcus Garvey, New York.

Gdula M.

2017 Pożytki z klasowości. Klasy w Polsce i szanse zmiany społecznej, w: M. Gdula, M. Sutowski (red.), Klasy w Polsce. Teorie, dyskusje, badania, konteksty, Warszawa, s. $136-162$.

Goody J.

2011 Kradzież historii, przeł. J. Dobrowolski, Warszawa.

Gross J.T.

2000 Sąsiedzi. Historia zagłady żydowskiego miasteczka, Sejny.

Gregory D.

1997 Postcolonialism, w: T. Barfield (ed.), The Dictionary of Anthropology, Oxford.

Hai Y.

2009 The Making Of Mr Hai's Daughter: Becoming British, London.

Hall S.

2008 Tożsamość kulturowa a diaspora, przeł. K. Majer, „Literatura na Świecie”, nr 1-2, s. $165-183$.

Haushofer K.

1939 Grenzen in ihrer geographischen und politischen Bedeutung, Heidelberg-BerlinMagdeburg-Vowinckel.

Hobsbawm E., Ranger T. (red.)

2008 Tradycja wynaleziona, przeł. M. Godyń, F. Godyń, Kraków.

Jakubowska $\mathrm{H}$.

2014 Od egzotyki do nadziei białych, czyli (nie)mówienie o rasie $w$ dyskursie sportowym, „Tematy z Szewskiej”, nr 4(14), http://www.tematyzszewskiej.pl/index.php/2016/02/18/ od-egzotyki-do-nadziei-bialych-czyli-niemowienie-o-rasie-w-dyskursie-sportowym/ (dostęp: 20.07.2017).

Jarvie I.C.

1982 Popper on the Difference between the Natural and the Social Sciences, w: P. Levinson (ed.), In Pursuit of Truth. Essays on the Philosophy of Karl Popper on the Occasion of His 80th Birthday, Atlantic Highlands NJ, s. 83-107.

Kaczmarek L.

2008 Fidżi: dzieje i barwy wielokulturowości, Poznań.

Kaczmarek $€$.

2011 System neotradycyjny i polityka etniczna na Fidzi, w: W. Dohnal, A. Posern-Zieliński (red.), Antropologia i polityka. Szkice z badań nad kulturowymi wymiarami wła$d z y$, Warszawa, s. 103-123.

2014 Kategorie kultury publicznej służace konserwowaniu relacji władzy. Rasa i klasa w kontekście (post)kolonialnym, „Pogranicza. Studia Społeczne”, nr XXIII, s. 7-40.

Kaczmarek Ł., Ładykowski P.

2012 Gdy granice przekracza miasto: przygraniczny transnacjonalizm $w$ okolicach Szczecina, w: M. Buchowski, J. Schmidt (red.), Imigranci: między izolacją a integracją, Prace KNE PAN nr 18, Poznań, s. 273-289. 
Kaczmarek Ł., Parowicz I.

2013 Kingston: kolonialne ślady w tożsamości przestrzennej, „Journal of Urban Ethnology", nr 10, s. 33-45.

Kołodziejczyk D.

2010 Postkolonialny transfer na Europe Srodkowo-Wschodnia, „Teksty Drugie: Teoria Literatury, Krytyka, Interpretacja”, nr 5(125), s. 22-39.

Kossina G.

1912 Die deutsche Vorgeschichte, eine hervorragend nationale Wissenschaft, Leipzig.

Kossobudzka M.

2018 Koniec świata przetrwaja kobiety. Sa silniejsze od mężczyzn, http://wyborcza. pl/7,75400,22964237,armagedon-przetrwaja-kobiety-sa-silniejsze-od-mezczyzn.html (dostęp: 31.01.2018).

Kostrzewski J.

1961 Zagadnienie ciągłości zaludnienia ziem polskich w pradziejach (od połowy II tysiąclecia p.n.e. do wczesnego średniowiecza), Poznań.

Kozierowski S.

1934 Atlas nazw geograficznych Słowiańszczyzny Zachodniej, wydanie specjalne, zeszyt I, Poznań, http://www.mapywig.org/m_documents/PL/ATLAS_NAZW_GEOGRAFICZNYCH_SLOWIANSZCZYZNY_ZACHODNIEJ_ZESZYT_I.pdf (dostęp: 18.11.2014). Lal B.V.

1992 The Broken Waves: A History of Fiji Islands in the Twentieth Century, Honolulu.

Łowmiański H.

1967 Początki Polski. Z dziejów Słowian w I tysiacleciu n.e., t. III, Warszawa.

Łukasik K.

2017 Czy twoja orientacja seksualna jest wypisana na twarzy? Awantura o pewien komputerowy algorytm, „Wyborcza.pl”, http://wyborcza.pl/7,75400,22605243, seksizm-trafia-do-cyberswiata.html (dostęp: 05.07.2017).

Macnaught T.

1982 The Fijian Colonial Experience: A Study of Neotraditional Order under British Colonial Rule Prior to World War II, Canberra.

Morawiecki M.

2018a Premier Mateusz Morawiecki: traktujemy walkę o prawdę historyczna jako jeden z naszych absolutnie najwyższych celów, https://www.premier.gov.pl/wydarzenia/aktualnosci/premier-mateusz-morawiecki-traktujemy-walke-o-prawde-historyczna-jakojeden-z.html (dostęp: 11.02.2018).

2018b Premier Mateusz Morawiecki w Monachium: Życzyłbym sobie, żeby w ramach NATO powstawała coraz silniejsza struktura obronna w Europie, https://www.premier.gov.pl/ wydarzenia/aktualnosci/premier-mateusz-morawiecki-w-monachium-zyczylbymsobie-zeby-w-ramach-nato.html (dostęp: 17.02.2018).

Moskal W.

2012 Kto wygrywa igrzyska olimpijskie i dlaczego mutanty, http://wyborcza.pl/1,75400, 12287648,Kto_wygrywa_igrzyska_olimpijskie_i_dlaczego_mutanty.html (dostęp: 10.08.2012).

Nettleford R.M.

1972 Identity, Race and Protest in Jamaica, New York.

Obrębski J.

1936 Recenzja: J. Falkowski, B. Pasznycki, „Na pograniczu łemkowsko-bojkowskim”, „Sprawy Narodowościowe”, t. 10, nr 1-2, s. 156-158. 
Ortner S.B.

2004 Pokolenie X. Antropologia w świecie nasyconym mediami, przeł. M. Kempny, w: M. Kempny, E. Nowicka (red.), Badanie kultury. Elementy teorii antropologicznej. Kontynuacje, Warszawa, s. 420-447.

Petty W.

1690 Political Arithmetics, London.

Popper K.R.

1957 The Poverty of Historicism, London.

Radio elka.pl

2013 Chwała bohaterom, relacja J. Adamek, 27 grudnia (dostęp: 27.12.2017).

Ritz G.

1999 Dyskurs płci w ujęciu porównawczym, „Teksty Drugie: Teoria Literatury, Krytyka, Interpretacja" nr 5 (58), s. 117-123.

Said E.

1991 Orientalizm, przeł. W. Kalinowski, Warszawa.

2003 Orientalism: Western Concepts of the Orient, London.

Sauvy A.

1952 Trois mondes, une planète, „L'Observateur”, 14 août, no 118, s. 14, http://www. homme-moderne.org/societe/demo/sauvy/3mondes.html

Semmel B.

1960 Imperialism and Social Reform: English Social-Imperial Thovght 1895-1914, Cambridge.

Sherlock P., Bennett H.

1998 The Story of Jamaican People, Ian Randle Publisher, Princeton.

Strauchold G.

2012 „Jest dobrze, będzie jeszcze lepiej”. Nowe granice zachodnie polski w dyskursie publicystyczno-naukowym lat 40. XX wieku, „Rocznik Lubuski”, t. 38, cz. 1.

Strutyński M.

2014 Rasizm $w$ koncepcjach środowisk politycznych $w$ Polsce na przełomie XX i XXI wieku, „Tematy z Szewskiej”, nr 4(14), www.tematyzszewskiej.pl/wp-content/uploads/2016/02/TzSz-414-26-021.34-50.pdf (dostęp: 19.07.2016).

Tinker $\mathrm{H}$.

1974 A New System of Slavery: The Export of Indian Labour Over Seas, 1830-1920, London.

Wieliński B.T.

2018 Premier Morawiecki nie odbudował polskiej reputacji. On ja jeszcze bardziej popsut, „Wyborcza”, 18 lutego, http://wyborcza.pl/7,75968,23038103,premier-morawiecki-nie-odbudowal-polskiej-reputacji-on-ja-jeszcze.html (dostęp: 18.02.2018).

Wirtualna Polska

2018 Zarzuty Morawieckiego wobec Rosji. „Hybrydowa agresja”, oprac. K. Pietrzak, https://wiadomosci.wp.pl/zarzuty-morawieckiego-wobec-rosji-hybrydowa-agresja6221015628281473a (dostęp: 16.02.2018).

Wolf E.R.

1994 Perilous Ideas. Race, Culture, People, „Current Anthropology”, vol. 35, no. 1, s. $1-7$.

Woźniak O.

2015 Obcy. Dlaczego ich nie lubimy?, „Wyborcza.pl”, http://wyborcza.pl/1,145452, 18582915,obcy-dlaczego-ich-nie-lubimy.html (dostęp: 21.12.2015). 
2017 Patriotyzm jest $w$ nas zakodowany biologicznie. Niestety, szowinizm też, „Wyborcza. pl”, http://wyborcza.pl/7,75400,22136469, patriotyzm-jest-w-nas-zakodowany-biologicznie-niestety-szowinizm.html (dostęp: 23.07.2017).

Wrzesiński W.

1992 Sąsiad. Czy wróg? Ze studiów nad kształtowaniem obrazu Niemca w Polsce w latach 1795-1939, Wrocław.

Wysokie Obcasy (MJ, JR, AO)

2012 Ile odsłoni Polka? W dużym mieście niedużo, ale im dalej na wschód... Fragmenty wywiadu $z$ dr. Tomaszem Szlendakiem, „Wysokie Obcasy Extra”, http://www.wysokieobcasy.pl/wysokie-obcasy/12,97398,12593196,Wysokie_Obcasy_Extra_Ile_odsloni_Polka_W_duzym_miescie.html?v=1\&obxx=12593196 (dostęp: 02.10.2012).

Zarządzenie

1946 Zarządzenie Ministrów Administracji Publicznej i Ziem Odzyskanych z dnia 7 maja 1946 r., http://isap.sejm.gov.pl/DetailsServlet?id=WMP19460440085 (dostęp: 18.11.2014).

Zimmerman A.

2006 Decolonizing Weber, „Postcolonial Studies”, nr 9(1), s. 53-79. 